\title{
The First Record of Kudoa megacapsula (Myxozoa: Multivalvulida) from Farmed Yellowtail Seriola quinqueradiata Originating from Wild Seedlings in South Korea
}

\author{
Hiroshi Yokoyama ${ }^{1 *}$, Tetsuya Yanagida ${ }^{1}$ and Iwao Takemaru² \\ ${ }^{1}$ Department of Aquatic Bioscience, Graduate School of Agricultural and Life Sciences, \\ The University of Tokyo, Tokyo 113-8657, Japan \\ ${ }^{2}$ Kagoshima Prefectural Fisheries Promotion Division, \\ Kagoshima 890-8577, Japan
}

(Received July 10, 2006)

\begin{abstract}
Kudoa megacapsula was found in the somatic muscle of yellowtail Seriola quinqueradiata, which were raised from wild seedlings (juveniles) imported from South Korea. Numerous parasitic foci, $2-3 \mathrm{~mm}$ in size, were recognized as filamentous 'black cysts' in the skeletal muscle, while no muscle liquefaction was observed. The spores $(34.6 \times 28.9 \mu \mathrm{m}$ in mean size) were cruciform to stellate and had four distinct winglike projections, in which one extremely large and three small polar capsules were present. These morphological characteristics and small subunit ribosomal DNA sequences of the myxozoan were consistent with those of $K$. megacapsula, which was originally described from red barracuda Sphyraena pinguis caught off the coast of China. Histopathological observation revealed that plasmodia developed intracellularly within the myofibrils, followed by encapsulation by host's fibroblast layers, resulting in granulomatous inflammation.
\end{abstract}

Key words: Kudoa megacapsula, Myxozoa, Seriola quinqueradiata, yellowtail, SSU rDNA, histopathology

\begin{abstract}
Aquaculture of yellowtail Seriola quinqueradiata in Japan has developed by taking advantage of abundant supplies of wild juveniles (mojako) as culture seedlings. It has been estimated that 200 to 800 million mojako exist off the coast of Japan (Nakada, 2002). Recently, however, the number of mojako being caught has gradually decreased, possibly because of global climate changes and/or overfishing. Hatchery-bred juveniles have been raised successfully in some facilities, but the quantity of supply for aquaculture is still insufficient. When shortages of wild-caught mojako in Japanese waters occur, yellowtail juveniles have been occasionally imported from South Korea. Besides them, many other fish species, e.g., amberjack Seriola dumerili, red sea bream Pagrus major and Chinese sea bass Lateolabrax sp., have been introduced to Japan from China or other Asian countries. However, several
\end{abstract}

\footnotetext{
* Corresponding author

E-mail: ayokoh@mail.ecc.u-tokyo.ac.jp
}

exotic parasites were translocated through fish movement, creating serious economic losses for the domestic aquaculture industry (Ogawa et al., 1995; Yokoyama et al., 2003; Ogawa, 2005).

From October 1999 to January 2000, an uncommon myxosporean infection was evident in the somatic muscle of farmed yellowtail, which were raised in Japan using wild seedlings imported from South Korea. Disease outbreak occurred in at least four prefectures in western Japan. It seemed likely that the spore shape resembled Kudoa megacapsula that was recently recorded from wild red barracuda Sphyraena pinguis caught along the coast of China, though the gross lesions were apparently different from those of $K$. megacapsula that exhibited post-mortem myoliquefaction in the host fish (Yokoyama and Itoh, 2005). Due to the unsightly appearance of the infected yellowtail and a relatively high prevalence (ca. $12 \%$ ), this parasite was considered as a potential threat to yellowtail culture. In the present study, we aimed to identify the 
myxozoan parasite, particularly by comparison with $K$. megacapsula, using morphological and molecular analyses.

\section{Materials and Methods}

Fish sampling and morphological examination

Ten cultured yellowtail (1-year-old, mean body weight, $3978 \mathrm{~g}$; mean fork length, $61.2 \mathrm{~cm}$ ) were randomly collected from an infected stock of a fish farm in Japan on 1st December, 1999. Following removal of the head and internal organs, fish were filleted and then investigated visually. The number of 'black cysts' on the fillets was counted to determine the intensity of infection. For morphological and molecular analyses, several infected yellowtail (both 0-year- and 1-year-old) were transferred to our laboratory (The University of Tokyo) from a fish farm in January 2000 , and kept frozen $\left(-20^{\circ} \mathrm{C}\right)$ until required. Thawed muscle tissues were examined macroscopically. Wet-mount preparations of muscle lesions were examined using light microscope. Descriptions and measurements of spores were made according to Langdon (1991) and Yokoyama and Itoh (2005). Digital images were taken under an oil immersion objective and measurements were made for 20 spores from multiple images.

To conduct histopathological observations of the myxozoan infection, 1-year-old yellowtail showing the typical signs of infection were collected on 5th October, 1999. To investigate earlier stages of infection, additional samples of 0 -year-old yellowtail were obtained from the same farm on 13th January, 2000. The muscle tissues were cut into small blocks, fixed in 10\% buffered formalin and processed for routine histology. Paraffin sections were cut at $5 \mu \mathrm{m}$, stained with hematoxylin and eosin (H \& E) and observed using light microscope.

\section{Molecular analysis}

The muscle lesions were fixed in $90 \%$ ethanol, and DNA of myxozoans was extracted using a QIAamp DNA Mini Kit (Qiagen Inc., Germany). To amplify the small subunit ribosomal DNA (SSU rDNA) of myxozoans, primer pairs 18e (Hillis and Dixon, 1991) - Kudr1 (Yokoyama and Itoh, 2005) and Kud6f (Whipps et al., 2003) $-18 \mathrm{~g}$ (Hillis and Dixon, 1991) were used. PCR reactions were carried out in $20 \mu \mathrm{L}$ of total volume, containing $0.1 \mu \mathrm{L}$ of Takara Ex Taq ${ }^{\mathrm{TM}} \mathrm{HS}(5 \mathrm{U} / \mu \mathrm{L}$; Takara Bio Inc., Japan), $2 \mu \mathrm{L}$ of $10 \times$ Ex Taq $^{\text {TM }}$ Buffer, $1.6 \mu \mathrm{L}$ of dNTP ( $2.5 \mathrm{mM}$ each), $0.6 \mu \mathrm{L}$ of each primer $(25 \mathrm{pmol} / \mu \mathrm{L})$ and $1.0 \mu \mathrm{L}$ of extracted DNA suspension (10 ng/ $\mu \mathrm{L}$ ). PCRs were performed for 35 cycles consisting of $94^{\circ} \mathrm{C}$ for $30 \mathrm{sec}, 57.5^{\circ} \mathrm{C}$ for $45 \mathrm{sec}, 72^{\circ} \mathrm{C}$ for $90 \mathrm{sec}$, preceded by an initial denaturation at $95^{\circ} \mathrm{C}$ for $3 \mathrm{~min}$, and followed by a final extention at $72^{\circ} \mathrm{C}$ for $7 \mathrm{~min}$. PCR products were ligated into a vector (pT7Blue T-Vector,
Novagen, U.S.A.), which was used to transform competent Escherichia coli cells (JM109, Takara Bio Inc., Japan). DNA sequences were obtained from 3 different clones using several designed probes and sequencing was performed using a BigDye ${ }^{\mathrm{TM}}$ Terminator v3.0 cycle sequencing ready reaction kit and visualized on an $A B I$ 310 automatic gene sequencer (Applied Biosystems Inc., U.S.A.). The resulting sequences were compared with those of Kudoa megacapsula ex Sphyraena pinguis (GenBank accession number: AB188529).

\section{Results}

\section{Gross observation}

Numerous parasitic foci, $2-3 \mathrm{~mm}$ in length, were recognized as filamentous or sesamoid 'black cysts' in the skeletal muscle of yellowtail (Fig. 1). The 'cysts' were either uniformly or unevenly distributed through the interior muscle (Fig. 2) and on the flesh below the skin. Softening of muscle tissue was not observed. Six out of ten fish examined were found to be infected. Mean intensity of infection was 69 ('cysts' per infected fish), ranging from 22 to 157 .

\section{Morphological examination}

Intact spores were collected principally from 0-year-
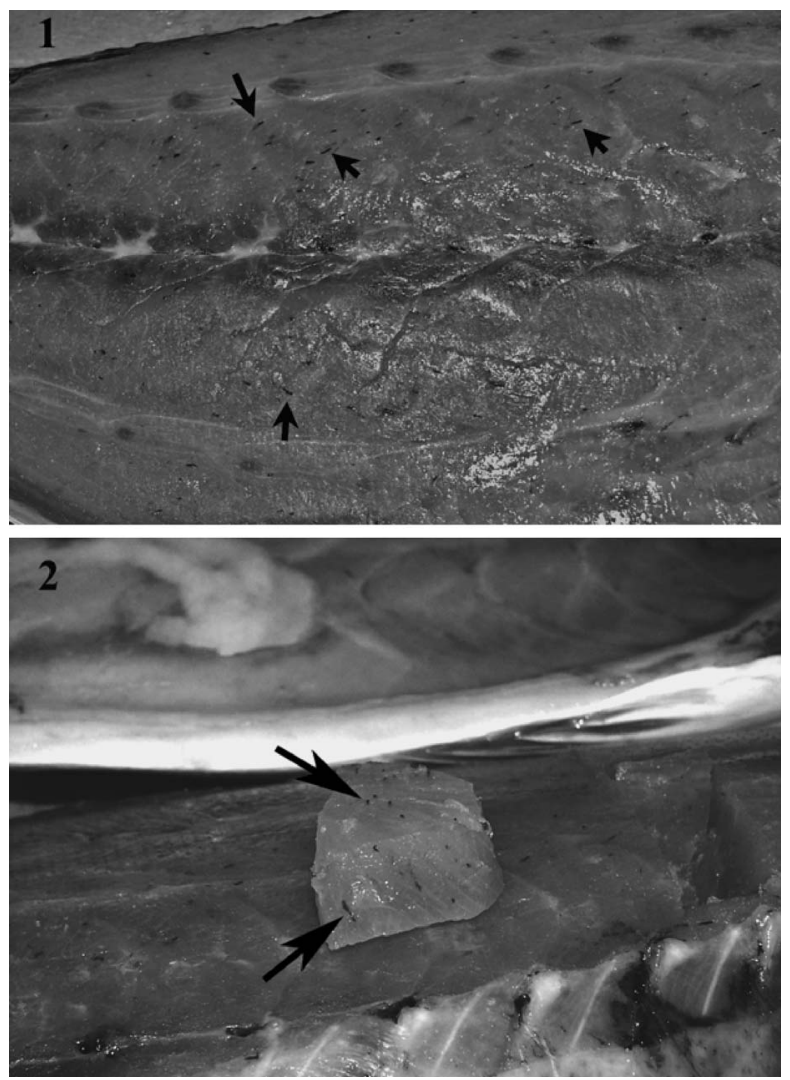

Figs. 1 \& 2. A fillet of yellowtail Seriola quinqueradiata infected with Kudoa megacapsula. Arrows show the filamentous 'black cysts'. 

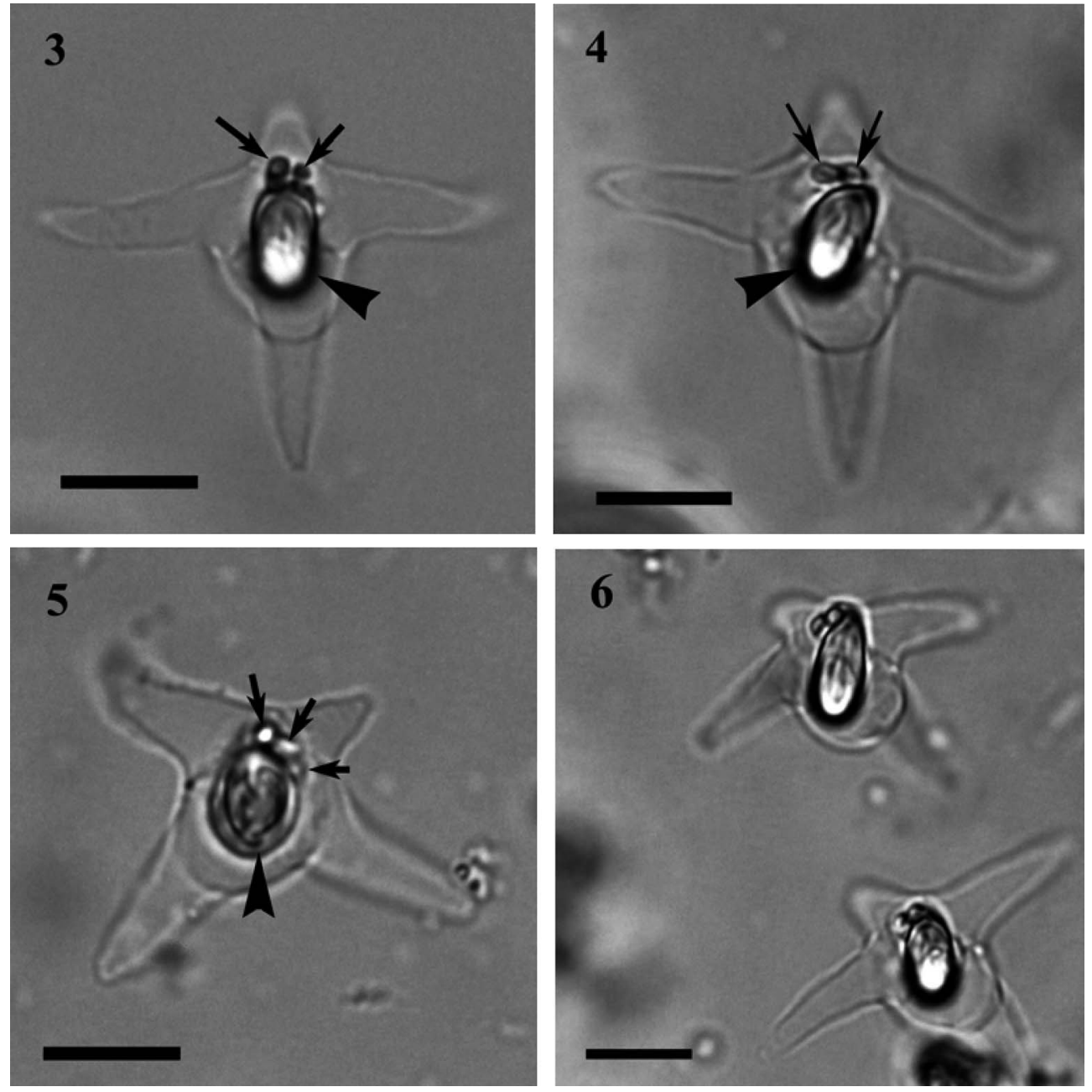

Figs. 3-6. Fresh spores of Kudoa megacapsula from yellowtail. Bars $=10 \mu \mathrm{m}$. Arrowheads and arrows show the large and small polar capsules, respectively.

Table 1. Comparison of spore dimensions (mean; range in parentheses) of Kudoa megacapsula

\begin{tabular}{|c|c|c|c|c|c|c|c|c|c|}
\hline \multirow[b]{2}{*}{ Host } & \multicolumn{4}{|c|}{ Spore $(\mu \mathrm{m})$} & \multicolumn{2}{|c|}{$\begin{array}{l}\text { Large polar capsule } \\
\qquad(\mu \mathrm{m})\end{array}$} & \multicolumn{2}{|c|}{$\begin{array}{l}\text { Small polar capsule } \\
\qquad(\mu \mathrm{m})\end{array}$} & \multirow[b]{2}{*}{ Reference } \\
\hline & $\begin{array}{l}\text { Max. } \\
\text { thickness }\end{array}$ & $\begin{array}{c}\text { Min. } \\
\text { thickness }\end{array}$ & Width & Length & Length & Width & Length & Width & \\
\hline Sphyraena pinguis & $\begin{array}{c}40.0 \\
(30.3-44.7)\end{array}$ & $\begin{array}{c}30.9 \\
(25.6-34.9)\end{array}$ & $\begin{array}{c}12.0 \\
(11.0-12.9)\end{array}$ & $\begin{array}{c}13.4 \\
(9.3-15.4)\end{array}$ & $\begin{array}{c}12.7 \\
(11.7-14.2)\end{array}$ & $\begin{array}{c}5.8 \\
(4.9-6.8)\end{array}$ & $\begin{array}{c}2.8 \\
(1.5-4.4)\end{array}$ & $\begin{array}{c}1.2 \\
(1.0-1.5)\end{array}$ & $\begin{array}{l}\text { Yokoyama and } \\
\text { Itoh (2005) }\end{array}$ \\
\hline Seriola quinqueradiata & $\begin{array}{c}34.6 \\
(31.8-38.1)\end{array}$ & $\begin{array}{c}28.9 \\
(25.5-33.0)\end{array}$ & $\begin{array}{c}11.4 \\
(10.8-12.0)\end{array}$ & $\begin{array}{c}13.8 \\
(11.0-15.0)\end{array}$ & $\begin{array}{c}12.6 \\
(11.4-14.0)\end{array}$ & $\begin{array}{c}5.3 \\
(4.8-6.9)\end{array}$ & $\begin{array}{c}2.7 \\
(2.0-4.0)\end{array}$ & $\begin{array}{c}1.2 \\
(1.0-2.0)\end{array}$ & This study \\
\hline
\end{tabular}

old yellowtail. The spores were stellate to cruciform in apical view (Figs. 3-6). The four distinct projections were unequal in length, tapered and slightly curved. Four polar capsules, one extremely larger than the other three, were pyriform in shape, pointed anteriorly. The spore dimensions $(n=20)$ are summarized in Table 1. The dark muscle lesions in 1-year-old yellowtail in most cases contained only large polar capsules, probably remnants of disintegrated spores. Brown or black pigmentation was also evident in close association with degenerating polar capsules.

\section{Histopathological examination}

Multinuclear plasmodia, developing within the myofibrils of the 0-year-old yellowtail, were observed to replace the sarcoplasm with a mass of developing and mature spores (Fig. 7). No host response directly related to the developing parasite was found at muscle fibers. At the same time, however, encapsulated small plasmodia were occasionally observed (Fig. 8). 

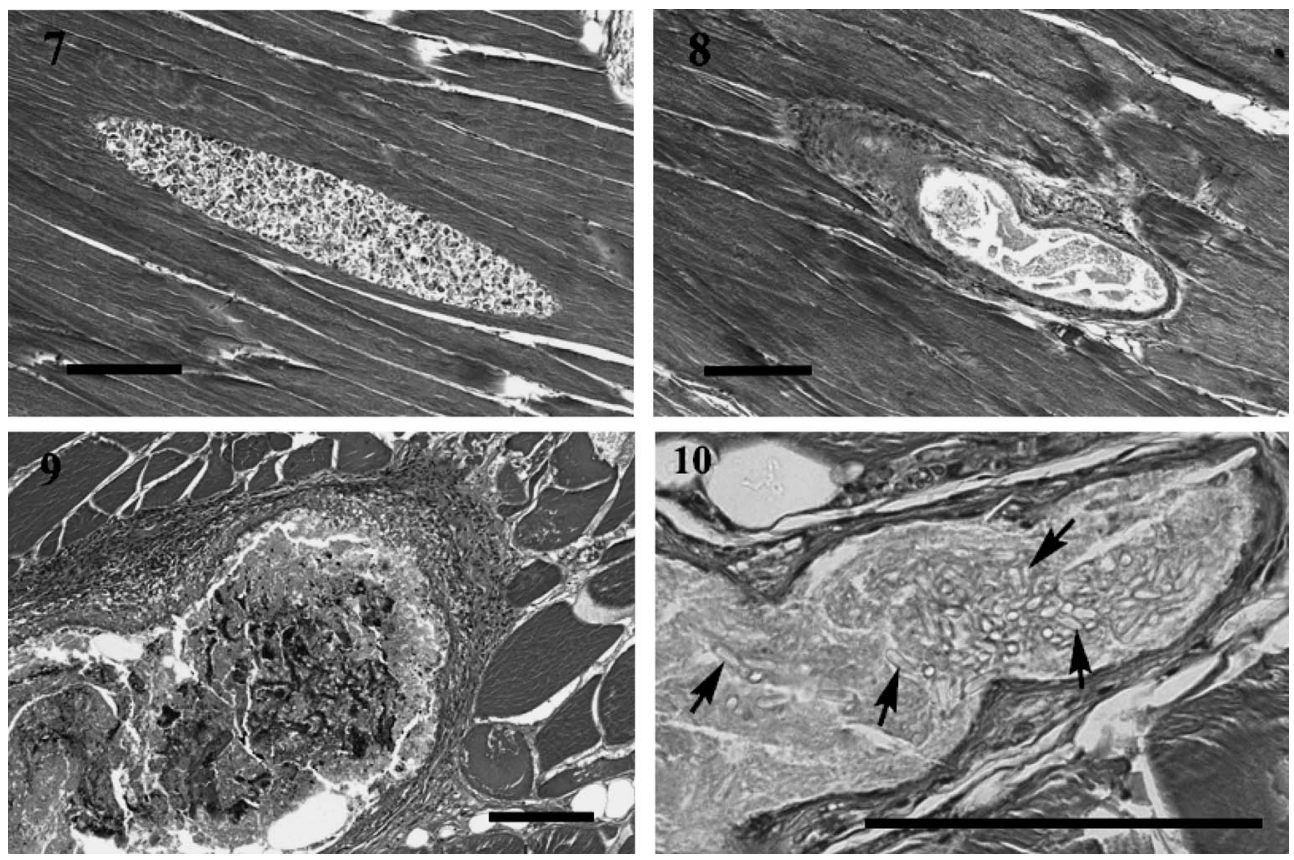

Figs. 7-10. Histological sections of the skeletal muscle of yellowtail infected with Kudoa megacapsula. H \& E stain. Bars = 100 $\mu \mathrm{m}$. 7: a fusiform plasmodium developing within the myofibril of 0-year-old fish, 8: an encapsulated small plasmodium in the muscle of 0-year-old fish, 9: a giant granuloma containing necrotic mass, black pigments and destroyed spores in the muscle of 1-year-old fish. 10: degenerating large polar capsules (arrows) accumulated in a granuloma.

Although mature and degenerating spores were packed within encapsulated plasmodia, no presporogonic stages were detected. 'Black cysts' in the 1-year-old fish were composed of destroyed spores and phagocytic infiltrates, with surrounding thick layers of fibroblasts. Granulomatous inflammatory response was evident, producing a large encapsulated granuloma that contained a necrotic mass, black pigments (possibly melanin) and degenerating large polar capsules in the center (Figs. 9 and 10). Neither myoliquefaction, nor spore dispersion into extracellular spaces, were observed.

\section{Molecular analysis}

SSU rDNA sequences of 1564 bp were obtained from myxozoan spores infecting the muscle of yellowtail. The sequence shared a $99.8 \%$ identity to that of $K$. megacapsula, which were originally described from red barracuda (Yokoyama and Itoh, 2005). The sequence data determined in the present study have been deposited in GenBank: Kudoa megacapsula; accession number AB263074.

\section{Discussion}

On the basis of morphological and molecular results in this study, the myxozoan in the somatic muscle of yellowtail was identified as K. megacapsula. Although spore sizes in the present study are slightly smaller than the original description of Yokoyama and Itoh (2005), the size of spore projection is likely variable, resulting in a relatively wide variation in the thickness of spores. It should be also considered that host effects may influence the spore size (Yanagida et al., 2004). Nevertheless, the remarkable spore morphology of $K$. megacapsula, the presence of the extremely large polar capsule and four winglike projections, make it distinct from all other hitherto described Kudoa species. Molecular analysis of SSU rDNA confirms the validity of the identification of this parasite. SSU rDNA gene sequences of myxozoans can be variable between even closely related taxa, and intraspecific variation of $0.9 \%$ within Kudoa thyrsites SSU rDNA sequences has been documented (Yokoyama et al., 2004). Yanagida et al. (2004) also reported a sequence difference of $0.4 \%$ between European and Japanese isolates of Enteromyxum leei. Thus, the minor difference $(0.2 \%)$ between the originally described $K$. megacapsula and the present parasite is considered to be insignificant.

It is noticeable that the host response to $K$. megacapsula in yellowtail differed from that in red barracuda, which exhibited post-mortem myoliquefaction. Although Yokoyama and Itoh (2005) could not find any young plasmodia of $K$. megacapsula parasitizing the muscle fibers of red barracuda, it has been reported that Kudoa spp. causing the muscle liquefaction develop consistently within the myofibrils (Moran et al., 1999). The histological observations in the present study have revealed for the first time that plasmodia of $K$. megacapsula develop intracellularly in the myofibers of 0 -year-old yellowtail, suggesting the potential of muscle 
degeneration after harvest. However, liquefied lesions have not been observed in either 0 - or 1-year-old yellowtail examined here. Patashnik et al. (1982) documented that proteolytic enzymes of Kudoa spp. are removed by blood circulation while fish is alive, but after death the enzymes diffuse into adjacent muscle resulting in myoliquefaction. It has also been demonstrated that only pre-sporogonic components (not mature spores) in developing plasmodia are responsible for enzyme production, while 'black cysts' are proteolytically inactive (Patashnik et al., 1982; Stehr and Whitaker, 1986). In case of the 1-year-old fish in the present study, it is conceivable that the $K$. megacapsula is no longer proteolytically active because of encapsulation by thick collagenous layers. It remains to be clarified whether myoliquefaction occurs in 0 -year-old yellowtail harboring intracellular young plasmodia of $K$. megacapsula. However, it is presumed that disintegration of infected myofibrils immediately elicits the host response, followed by rapid encapsulation, not allowing time for diffusion of the proteolytic enzymes into the neighboring tissues.

It may be speculated that $K$. megacapsula in the present study was introduced into Japan from South Korea through the unregulated importation of yellowtail juveniles. As far as we know, K. megacapsula has not been found in cultured yellowtail using domestic seedlings at the same year classes. Circumstantial evidence strongly suggests that the source of this parasite is South Korea. Similar signs of infection have been often observed in the skeletal muscle of farmed amberjack, imported from China at the seedling stage (unpublished obs.). Although the amberjack parasite could not be fully identified because only large polar capsules were detected, the source of the amberjack fry is consistent with the type locality of $K$. megacapsula (Yokoyama and Itoh, 2005). It seems likely that the geographical distribution of $K$. megacapsula is the continental side of the Sea of Japan and the East China Sea. It is still unknown whether the life-cycle of this parasite has been established in Japanese waters, but there is so far no evidence that domestically produced yellowtail suffer from $K$. megacapsula infection. However, in the light of the similar aquatic environment among Korea, China and south-western Japan, it seems possible that this parasite could easily establish an infection cycle in Japan. Human activities such as fish transportation for aquaculture have been recognized as one of major causes of the alarming increase in rate for emerging diseases (Harvell et al., 1999). There is a need for quarantine procedures to be established, as well as development of hatchery-produced juveniles on a commercial scale.

\section{Acknowledgements}

We greatly appreciate Dr. Kathryn Hall for reviewing this manuscript, and several yellowtail farmers for their kind cooperation with this study.

\section{References}

Harvell, C. D., K. Kim, J. M. Burkholder, R. R. Colwell, P. R. Epstein, D. J. Grimes, E. E. Hofmann, E. K. Lipp, A. D. M.E. Osterhaus, R. M. Overstreet, J. W. Porter, G. W. Smith and G. R. Vasta (1999): Emerging marine diseases climate links and anthropogenic factors. Science, 285, $1505-1510$.

Hillis, D. M. and M. T. Dixon (1991): Ribosomal DNA: Molecular evolution and phylogenetic inference. Quart. Rev. Biol., $66,411-453$

Langdon, J. S. (1991): Myoliquefaction post-mortem ('milky flesh') due to Kudoa thyrsites (Gilchrist) (Myxosporea: Multivalvulida) in mahi mahi, Coryphaena hippurus L. J. Fish Dis., 14, 45-54.

Moran, J. D. W., D. J. Whitaker and M. L. Kent (1999): A review of the myxosporean genus Kudoa Meglitsch, 1947, and its impact on the international aquaculture industry and commercial fisheries. Aquaculture, 172, 163-196.

Nakada, M. (2002): Yellowtail culture development and solutions for the future. Rev. Fish. Sci., 10, 559-575.

Ogawa, K. (2005): Parasitic diseases of fishes. Nippon Suisan Gakkaishi, 71, 650-653 (In Japanese).

Ogawa, K., M. G. Bondado-Reantaso, M. Fukudome and H. Wakabayashi (1995): Neobenedenia girellae (Hargis, 1955) Yamaguti, 1963 (Monogenea: Capsalidae) from cultured marine fishes of Japan. J. Parasitol., 81, 223-227.

Patashnik, M., H. S. Groninger Jr., H. Barnett, G. Kudo and B. Koury (1982): Pacific whiting, Merluccius productus: I. Abnormal muscle texture caused by myxosporidian-induced proteolysis. Mar. Fish. Rev., 44, 1-12.

Stehr, C. and D. J. Whitaker (1986): Host-parasite interaction of the myxosporeans Kudoa paniformis Kabata \& Whitaker, 1981 and Kudoa thyrsites (Gilchrist, 1924) in the muscle of Pacific whiting, Merluccius productus (Ayres): an ultrastructural study. J. Fish Dis., 9, 505-517.

Whipps, C. M., R. D. Adlard, M. S. Bryant, R. J. G. Lester, V. Findlay and M. L. Kent (2003): First report of three Kudoa species from eastern Australia: Kudoa thyrsites from mahi mahi (Coryphaena hippurus), Kudoa amamiensis and Kudoa minithyrsites $\mathrm{n}$. sp. from sweeper (Pempheris ypsilychnus). J. Euk. Microbiol., 50, 215-219.

Yanagida, T., Y. Nomura, T. Kimura, Y. Fukuda, H. Yokoyama and K. Ogawa (2004): Molecular and morphological redescriptions of enteric myxozoans, Enteromyxum leei (formerly Myxidium sp. TP) and Enteromyxum fugu comb. $\mathrm{n}$. (syn. Myxidium fugu) from cultured tiger puffer. Fish Pathol., 39, 137-143.

Yokoyama, H. and N. Itoh (2005): Two multivalvulid myxozoans causing postmortem myoliquefaction: Kudoa megacapsula n. sp. from red barracuda (Sphyraena pinguis) and Kudoa thyrsites from splendid alfonso (Beryx splendens). J. Parasitol., 91, 1132-1137.

Yokoyama, H., H. Kawakami, H. Yasuda and S. Tanaka (2003): Henneguya lateolabracis sp. n. (Myxozoa: Myxosporea), the causative agent of cardiac henneguyosis in Chinese sea bass Lateolabrax sp. Fish. Sci., 69, 1116-1120.

Yokoyama, H., C. M. Whipps, M. L. Kent, K. Mizuno and H. Kawakami (2004): Kudoa thyrsites from Japanese flounder and Kudoa lateolabracis $\mathrm{n}$. sp. from Chinese sea bass: causative myxozoans of post-mortem myoliquefaction. Fish Pathol., 39, 79-85. 